American Journal of Applied Sciences 6 (8): 1560-1566, 2009

ISSN 1546-9239

(C) 2009 Science Publications

\title{
Using Culture, Policy and Traditional Knowledge to Improve Engagement in Science Courses
}

\author{
${ }^{1}$ Lawrence K. Duffy, ${ }^{2}$ Catherine Hurt Middlecamp, ${ }^{1}$ Anna Godduhn and ${ }^{3}$ Cindy E. Fabbri \\ ${ }^{1}$ Department of Chemistry and Biochemistry, University of Alaska Fairbanks, Fairbanks, AK, 99775 \\ ${ }^{2}$ Department of Chemistry, University of Wisconsin-Madison, Madison, WI 53706 \\ ${ }^{3}$ School of Education and College of Natural Science and Mathematics, \\ University of Alaska Fairbanks, Fairbanks, AK 99775
}

\begin{abstract}
Problem statement: In our undergraduate science courses, we need to engage students by including the current issues and concerns of our students as well as recognizing the place-based context in which they learn. Including culture, policy and traditional knowledge when it intersects with a chemical principle and a challenging real world issue adds concreteness to the scientific process. Approach: Science Education for New Civic Engagement and Responsibilities (SENCER) is a national dissemination project for courses in science, technology, engineering and mathematics. SENCER courses connect science and civic engagement by teaching through complex, capacious, current and unresolved public issues to the underlying scientific principles. The more that our students were exposed to culturally responsive interdisciplinary science courses that encompass biocomplexity, the more prepared they will act as agents of long term stewardship through periods of rapid change and ecological challenge. It was therefore critical that issues such as sustainability, environmental health, food security, justice and precaution be integrated into science teaching. In studying public issues of the north, students and faculty can use examples from traditional knowledge to illustrate the use of science principles. Results: As part of the IPY UARCTIC effort, examples from climate change, nutrition, nuclear science and chemical ecology were developed to illustrate this integration. The courses adapted and delivered at an arctic university will illustrate the benefits of integrating social and cultural topics with science. Student responses showed an increase in interest in science. Conclusion: The adapt and adopt process is synergistic and should be goal oriented. This approach was especially relevant to minority and indigenous students who were engaged in the issues of their local community. The SENCER approach to arctic science creates a legacy of new, engaging courses in the north.
\end{abstract}

Key words: Civic engagement, radioactivity, ecology, chemistry, traditional knowledge, community

\section{INTRODUCTION}

“...[this] is the best course I have taken at this university for many reasons-the ability to successfully integrate science and the issues surrounding it being just one of many".

These lines, excerpted from a longer piece by a student in her final reflection piece for the course, would warm the heart of any instructor. They surely did so in the chilly north, where she was enrolled in the new course "Environmental Radioactivity, Stewardship and People of the North" at the University of Alaska Fairbanks (UAF). Even the dissatisfaction expressed by this student took a positive spin: "Most of my complaints would revolve around not learning enough- every issue seemed interesting enough to have an entire class about".

Similarly, other students reflected positively on their learning experiences. In the context of real-world issues, another student reported: “... my understanding has broadened". A third student exclaimed: "The subject is fascinating"! And a fourth quipped: "For oddities in the University of Alaska System, we were definitely top of the list. Interdisciplinary courses are a refreshing place to learn,...".

Given testimonials such as these, the reader might wonder what insights we might now offer on the process of "adapting and adopting" a science course by including engaging social issues. But those who have been through the process of designing a new course will

Corresponding Author: Lawrence K. Duffy, Department of Chemistry and Biochemistry, University of Alaska Fairbanks, Fairbanks, AK, 99775 
realize that student assessment is but one of many factors that determine the success of a course. We hope to offer the reader some general insights about the process of curriculum reform at a state university. One such insight relates to the development of the course itself. For example, adapting and adopting a previously existing course has practical limits. To be of use, the match between the model and the new course must be reasonably close. Nonetheless, the instructor must adapt and adopt from the model course judiciously, carefully tailoring the new course to meet the demands (and idiosyncrasies) of its new environment. That is, what are the social issues that students are concerned about? and, how do they relate to the social concepts the student needs to learn.

Another insight we offer relates to how a new course can reflect the realities both of our changing disciplines and (ultimately) of our changing planet. We will comment on the need to prepare our students for the challenges not only of today, but also those likely to arise tomorrow.

The SENCER (Science Engagement through New Civic Engagements and Responsibilities) national curriculum reform project is now almost a decade old ${ }^{[1]}$ and its philosophy has been described earlier ${ }^{[2,3]}$. For the Arctic, we find the original arguments for SENCER courses as compelling as they were in 2000; namely, that it is important that we as instructors make the connections between science, people and society more transparent. Equally important, through these connections, is to invite students to engage in the complex social issues that face us today locally, regionally and globally. If anything, the authors of this study would argue that issues such as climate change, energy production, sustainable use of resources, environmental justice and waste reduction are even more relevant today. As a 2008 report states ${ }^{[4]}$ :

"The commitment that many campuses have made to increased environmental sustainability and stewardship continues to be more than just rhetoric. A majority of schools currently have written declarations promoting environmental sustainability or stewardship or plan to develop them"

It is therefore critical that issues such as sustainability, environmental health, food security and precaution be integrated into science teaching. In studying public issues of the north, students and faculty can use examples from Traditional Knowledge to illustrate the use of chemical principles. As part of the IPY UARCTIC effort, examples from climate change, nutrition, nuclear science, chemical ecology and biotechnology were integrated with traditional knowledge into two courses (1) introduction to Radioactivity in the North and (2) chemistry and Complex Systems. Exposure to traditional knowledge broadens the average students' world view and strengthens not only their understanding of the scientific process but engages them in community issues ${ }^{[5]}$.

\section{MATERIALS AND METHODS}

The course "Environmental Radioactivity, Stewardship and People of the North" at the University of Alaska Fairbanks came into existence in 2007 by adapting/adopting one of the SENCER Model Courses $^{[5,6]}$. Currently, over 20 such model courses exist and each provides potential adapters with a syllabus, learning goals and assessment tools. The SENCER Model course, "Environmental Chemistry and Ethnicity" (subtitle of "Uranium and American Indians"), was first co-taught in 2002 at the University of WisconsinMadison by one of the authors of this study (CM) and Omie Baldwin and has evolved over time ${ }^{[7,8]}$. Initially, the story of the Navajo uranium miners was used to illustrate the complex relationships between a cultural group and radioactivity on our planet. Later, the course is taught from the story of the radium dial-painters in the 1920 s and the story of nuclear testing in Alaska in the 1950s to illustrate these same relationships ${ }^{[9-11]}$.

The new course at the UAF, originally titled "Environmental Radioactivity, Stewardship and People of the North", similarly teaches the complex relationships between people and radioactivity but in the context of the Arctic ${ }^{[11,12]}$.

Adaptation team: Because of the immediacy of the issue, the first IPY adapted course focused on the nuclear history of Alaska as part of the UARCTIC's International Polar Year course cluster ${ }^{[13]}$. Four people were involved in the creation of the course: the instructor of record (LD), a graduate student coinstructor (AG), an evaluator (CF) and a consultant who developed the course from which the new one was adapted and adopted (CM). The instructor taught the course as part of his regular teaching and administrative load. The graduate student co-instructed the course and collected the evaluation instruments. The student was supported for assisting in the course development through the grant and the evaluator and consultant were hired with grant funding. The consultant made site visits during the planning stage as well as during the project. The time commitments of all involved were reasonable and necessary to move the project forward. 


\section{RESULTS}

The revised course at UAF, renamed "Introduction to Radioactivity in the North", continues to teach the complex relationship between people and radioactivity in the context of the Arctic. Students learn how nuclear chemistry and environmental health relate to the everyday lives of people in the North, especially Alaska Natives and rural circumpolar people. Complex societal issues are central both to the storyline of the course and to the intellectual tasks required of the students. Using readings such as Firecracker Boys ${ }^{[11]}$ students:

- Became familiar with and were able to discuss the methods and ethical frameworks used by scientists and engineers

- Learned about historical events in the north and considered the role of this history and Alaska Native culture in environmental and nuclear issues

- Learned what questions to ask and how to predict potential hazards when given a scenario involving a particular radioactive substance or an issue such as the proposed "nuclear battery" in Galena, Alaska

Assessment from the SALG demonstrated the students showed gains in learning and interest in science.

The enrollment marketplace: To be successful, a new course must generate and maintain enrollment. As they say in real estate, it is a mater of "location, location, location". Both the home department of the course and its wider role in the whole university's curriculum need to be considered. More specifically, factors to consider in marketing any new course include: (1) Finding a department and course number, (2) Providing an incentive for students to enroll, (3) Overcoming any logistical obstacles, such as conflicts with other required courses and ultimately (4) Establishing a positive track record on campus with advisors and students. Relevant also to this particular course was to attract Alaska Native students. (Demographically, Alaska is $18 \%$ Alaska Native. The student body at UAF is about $16 \%$ Alaska Native. But few Alaska Native students enroll in physical science courses; they tend to study the humanities and social sciences).

The class was offered as an interdisciplinary 300level Liberal Arts and Science (LAS) class and enrollment was low. Enrollment remains low despite assessment, learning gains, increased advertisement and changing the name to "Radioactivity in the North". The problem in generating enrollment is significant no matter how well a course is appreciated by the enrolled students. In many universities, without being a required course for graduation, either as part of general education requirements or as part of a major, students are far less likely to enroll. Currently we are exploring teaching this course as "writing intensive" since a certain number of "W" classes are required, this could provide incentive for taking this elective class.

Ultimately, the ability of an interdisciplinary science course, which follows the SENCER philosophy, to fit within an institution's curriculum is the key element of any "adapt and adopt" initiative. Even though the experiences to date with this course indicate that students will have a highly positive learning experience, without substantial enrollment the course will not succeed. Furthermore, higher course enrollments make it possible to draw high profile speakers from the local community, such as tribal elders active in issues relating to the course.

Modifying chemistry in complex systems (Chem 100): Native Science methods included in scientific method discussions, traditional knowledge of ice and water in resources discussions, caribou gut ropes in the protein structure discussions and origins/identity in the genetic engineering discussion have been included in the UAF Chemistry of Complex Systems course. To adapt this course, we switched to the American Chemical Society text, "Chemistry in Context $^{[18]}$. This is not a traditional chemistry book, but one that follows an approach similar to SENCER. The goal of the text is to improve critical thinking ability and develop the skills that enable the student to make informed and reasonable decisions about technologybased issues. Similar to "Radioactivity in the North" we incorporated cultural viewpoints with the social issues (Table 3). Like the new course, the sencerized Chemistry in Complex Systems showed 20-40\% gains in learning outcomes and appreciation of science, as judged by SALG. Since Chem 100 is a core science course for non-science majors at UAF, the enrollment problem has improved with 25-40 students/semester.

\section{DISCUSSION}

Goal-based reverse engineering of a class: The instructors, the evaluator and the consultant worked as a team to develop the course, adapting and adopting materials from the SENCER Model Course, "Uranium and American Indians". Realistically, course development is constrained by the time and energy available from the instructors. This course was no exception, with all involved juggling other commitments and working under tight deadlines. The fact that we 
could adapt and adopt from an existing course greatly facilitated the course development process. Without funding for the evaluator and consultant (and their enthusiasm), the process of course development would have been extremely slow.

Learning goals should drive the development of any new course. Once in hand, these goals can be mapped into the course activities, learning assessments and any evaluation tools needed for external constituencies. As Barbara Tewksbury points out each year at the SENCER Summer Institutes, SENCER as a program is strongly goals-based and less focused on "coverage" than is typical for courses ${ }^{[14]}$.

One of the strengths of the SENCER method is the emphasis it places on higher order learning goals ${ }^{[15]}$. SENCER Model courses ${ }^{[1]}$, including the two from which we adapted, list higher order goals for their students. In the process of course development, we worked to avoid the "content trap"; that is, designing a course based on what content we thought we would "cover". Rather, we thought first about higher order learning goals for student learning and reverse engineered the course in the light of the goals set. This approach allows the instructor to engage the students in science by including social issues.

Table 1 shows both the goals for chemical content (excerpts) and the higher order learning goals (in full) from the existing course. The higher order goals include the ability to integrate, synthesize, incorporate feedback and apply knowledge to a new situation ${ }^{[16]}$. In contrast, lower order goals include the ability to explain a chemical concept, list a set of its attributes, understand the importance of a principle and to calculate a value from given data.

The goals for the new UAF course "Radioactivity in the North" are shown in Table 2. Although the language has been adapted to fit the new context, these goals are much the same as in the model course. Probably more than any other single factor, the congruency in course goals enabled the adapt-and-adopt process to be accomplished smoothly.

Course content and management: Radioactivity in the North, as the course currently is named, took the general goals and nuclear science of the model course and developed an Alaskan and Arctic context. The nuclear science content, of course, did not change, but the cultures and social context of the discussion most certainly did. Accordingly, texts relating to radioactivity in the north and local speakers were brought into the course syllabus. For "Chemistry in Complex Systems", the diversity of issues allowed us to increase the number of cultural issues discussed (Table 3).

Table 1: Goals for the model SENCER course, "Uranium and American Indians"

In this course, we hope you will acquire a deep understanding of the radioactive substances on our planet.

This includes your ability to:

- Know where one would expect to find radioactive substances on our planet

- Categorize radioactive substances on our planet as primordial, continuously replenished naturally, or human-made

- Use the concept of half-life to estimate when a radioactive substance will be "gone".

- By the context, interpret the term "radiation" as either nuclear (ionizing) or electromagnetic (either non-ionizing or ionizing)

- $\quad$ List different types of ionizing radiation (alpha/beta particles, gamma rays, X-rays) and compare them by mass, charge and ability to penetrate

- Given a radioisotope such as radium-226, cobalt-60, iodine-131, polonium-210, plutonium-240, or radon-222, being able to assess its health hazards (if any) based on factors such as the amount present, chemical behavior, physical form, half-life, type of radiation it emits and route of uptake (or not) into the body

- $\quad$ [others omitted...]

But please think beyond covering scientific content. This content is secondary to a set of higher order goals. These include your ability to:

- Integrate cultural and scientific issues

- Formulate questions about complex topics that interconnect people and science

- Handle complex ideas that do not have a single or best solution to all concerned

- Communicate technical scientific ideas to the general public, both in essay form and by drawing up "talking points".

- Learn something in one context and apply to another

- Engage others in learning about a topic that is important to you

- Take an informed stand on a controversial topic and be able to articulate your point of view to others

- Review another person's work/performance and offer helpful feedback.

- Review your own work, consider the feedback of others and make appropriate changes 
Table 2: Course philosophy and objectives for the new course, "Radioactivity in the North"

Our philosophy is one of integration: science, policy and culture in the circumpolar north! To achieve scientific literacy, students must come to understand key concepts and work through challenging problems of "traditional" chemistry. Since science occurs within systems of culture, economy and policy, we believe that students also should consider the context and linkages of scientific research, knowledge development and stakeholders' interests. Successful students will be able to apply what they have learned to new situations, frame useful questions about related issues and communicate effectively.

Students will learn how nuclear chemistry and biomedical science are relevant to the lives of people in the North, including Alaska Natives and rural circumpolar people. Complex societal issues will be central both to the storyline of the course and to the intellectual tasks required of the students taking this approach.

We want you to:

- Gain an essential understanding of nuclear chemistry, biochemical responses and related health research

- Become familiar with and be able to discuss the methods and ethical frameworks used by scientists and engineers

- Evaluate the scientific basis of nuclear policy concepts and the relevance to societal decisions

- Appreciate how culture pervades complex systems, participating in positive and negative feedback loops with policy

- Learn about historical events in the north and consider the role of this history and Alaska Native culture in environmental and nuclear issues

- Know what questions to ask and how to predict potential hazards when you are given a scenario involving a particular radioactive substance or an issue such as the proposed "nuclear battery" in Galena, Alaska and

- Think about how and to what extent, the science nuclear energy and weapons development is able to solve our problems-or create themusing the north as the context

Table 3: Lecture plan for Chemistry in Complex Systems (spring 2009)

\begin{tabular}{|c|c|c|c|c|c|}
\hline Week & Title & Chapter & Historical & Societal & Culture \\
\hline 1 & Scientific Method & 0 & Cisplatin Vitamin C & Technology & Alaska Native Knowledge \\
\hline 2 & States of Matter, Elements & 1 & Lavoiser & Air Pollution & Impacts of Mining \\
\hline 3 & Periodic Table, Molecules, Reactions, & 1 & Burning & Dalton's Theory & Impacts of Burning \\
\hline 4 & $\begin{array}{l}\text { Atomic Structure, Lewis Structure, } \\
\text { Chapman Cycle }\end{array}$ & 2 & Chapman & Pollution Policy & GAIA \\
\hline 5 & $\begin{array}{l}\text { Molecular Shape, Carbon Cycle, } \\
\text { Trophic Levels }\end{array}$ & 3 & CFC/POPS & Carbon Dioxide Policy & Arctic Council and AMAP \\
\hline 6 & Greenhouse Gases, Mass/Moles & 3 & IPY & & Global Transport \\
\hline 7 & Energy, Coal, Petroleum & 4 & Fossil Fuels & Climate Energy Era & $\begin{array}{l}\text { Ecosystems Impact and Native } \\
\text { Science }\end{array}$ \\
\hline 8 & Water, Intermolecular Forces & 5 & Linus Pauling & Water Quality & Ice and Its Names in the North \\
\hline 9 & PH, Acid Rain & 6 & Coal & Environmental Justice & Seven Generations \\
\hline 10 & Carbon Polymers & 9 & Aspirin & Biotech & Nature Medicine \\
\hline 11 & Problems/Aspirin & 10 & Plastics & Recycling & Birch Trees \\
\hline 12 & Steroids & 10 & Lipids & Human Enhancement & Diabetes \\
\hline \multirow[t]{2}{*}{13} & Nutrition Lipids & 11 & Global Food Systems & Obesity & Food Preservation \\
\hline & Carbohydrates Proteins & 11 & Proteins & Food Pyramids & Caribou Gut Products \\
\hline 14 & DNA & 12 & Watson & Profiling & Origins \\
\hline 15 & Genetic Engineering & 12 & Dolly & Cloning & Identity \\
\hline
\end{tabular}

The structural elements of the course were adapted practically wholesale as can be seen at the existing course web sites ${ }^{[7,8,12]}$. These elements included the class activities, grading rubrics and the use of the Student Assessment of Learning Goals for student course assessment. The assignments were modified to include either a book report or a service learning component. The first option allows students to follow up and report on a personal issue of interest; the latter gives students an opportunity to apply what they learn in the context of a local organization dealing with relevant issues.

The wider context of SENCER courses: Given the politically-charged atmosphere that surrounds science today, our students stand to benefit from a better understanding of both the role of science in policy and the role of policy in science. A strong understanding of the scientific method and its attendant uncertainty underlie the capacity of our citizens to make wellinformed choices. Interdisciplinary classes where the scientific issues behind real world situations are considered in a cross-cultural context provide perfect learning environment to learn the tools to make these choices. This is the SENCER approach, one that makes the science relevant to the student citizens, no matter their major and helps them learn a bit about real-world policy development. 
The atmosphere that surrounds science today also carries urgency. We as individuals, communities and societies are making decisions that will affect generations to come. Gro Brundtland clearly articulated this very concern in her foreword to the UN document.

Our common future: "If we do not succeed in putting our message of urgency through to today's parents and decision makers, we risk undermining our children's fundamental right to a healthy, life-enhancing environment. Unless we are able to translate our words into a language that can reach the minds and hearts of people young and old, we shall not be able to undertake the extensive social changes needed to correct the course of development.

To this end, we appeal to "citizens" groups, to non governmental organizations, to educational institutions and to the scientific community. They have all played indispensable roles in the creation of public awareness and political change in the past. They will play a crucial part in putting the world onto sustainable development paths, in laying the groundwork for our common future $^{[17]}$.

Thus, this urgent need for informed citizens lay at the heart of own efforts at course reform, as well as for the larger SENCER curriculum reform initiative. We knew that we needed to design a course that could enroll and engage a wide range of students.

\section{CONCLUSION}

The adapt-and-adopt process is synergistic, with both parties benefiting from each stage of the collaboration. Nonetheless, the devil is in the details! Creating a new course using an existing one as a model is far from algorithmic and any who propose to adaptand-adopt can avoid difficulties by carefully considering the issues named in this study. With each issue come choices and each choice carries ramifications that affect the success of the course.

The process of creating a course also contains intellectual challenges. In the process of working together, both parties we were forced out of their comfort zones to examine both existing practices, to critique each one and in some cases to create new ones. Ultimately, our task was to adapt and adopt existing course materials to accomplish a task of value to all involved; namely, to make explicit for our students the connections between nuclear chemistry and the concerns of a particular community of people. The SENCER approach to arctic science creates a legacy of new engaging courses in the north.

\section{ACKNOWLEDGMENT}

We are grateful to the students who invested their time and efforts in this course, teaching both us and each other. We also are grateful to Rich Boone, Pierre Forest, Ray Barnhardt, Karen Oates and Greg Van Doren for enlightening discussions. We would like to gratefully acknowledge the National Science Foundation for its continued support for science education through the SENCER project, funded by a CCLI National Dissemination Award, DUE-0455586 and this project, funded through a CCLI Adaption and Implementation Award, DUE-0632397.

\section{REFERENCES}

1. SENCER Home Page, 2008. http://www.sencer.net

2. Middlecamp, C.H. et al.., 2006. Chemistry, society and civic engagement (part 2): Uranium and American Indians. J. Chem. Educ., 83: 1301-1307. http://citation.nstl.gov.cn/detail.jsp?internal_id=667935

3. Middlecamp, C.H.., 2006. Chemistry, society and civic engagement (part 1): Uranium and American Indians. J. Chem. Educ., 83: 1308-1312. http://scifun.chem.wisc.edu/conversations/Convers ations4Teachers/2006/2004-1127f1.pdf

4. National Wildlife Federation, 2008. Campus environment 2008: A national report card on sustainability in higher education, trends and new developments in college and university leadership, academics and operations. http://www.nwf.org/campusEcology/campusreport card.cfm

5. Cajete, G., 1999. Native Science, Natural Laws of Interdependence. Clear Light Publishers, Santa Fe, ISBN: 1574160354, pp: 315.

6. Middlecamp, C.H., O. Baldwin, 2008. Uranium and American Indians, SENCER model course. http://serc.carleton.edu/sencer/uranium_american_i ndians/index.html

7. Middlecamp, C.H., 2008. Uranium and American Indians course web site. http://www.chem.wisc.edu/middlecamp/201-fall06/

8. Catherine, H.M., 2008. The radium girls and the firecracker boys course web site. http://www.chem.wisc.edu/middlecamp/251-spring08/

9. Clark, C., 1997. Radium Girls. University of North Carolina Press, Chapel Hill, ISBN: 0807846406, pp: 289.

10. Mullner, R., 1999. Deadly Glow: The Radium Dial Worker Tragedy. American Public Health Association, Washington DC., ISBN: 0875532454, pp: 175. 
11. O'Neill, D., 2007. The Firecracker Boys, HBombs, Inupiat Eskimos and the Roots of the Environmental Movement. Basic Books, New York, ISBN: 10: 0465003486, pp: 418.

12. Duffy, L.K., 2009. Radioactivity in the north course web site. http://www.uaf.edu/chem/493f08/syllabus.html

13. Duffy, L.K. and G, Anna, 2008. UAF College of natural science and mathematics newsletter. http://www.uaf.edu/cnsm/cnsm-newsletter/

14. Tewksbury, B., 2005. Designing a SENCER course: Don't just beat it to fit and paint it to match. http://www.sencer.net/Institutes/pdfs/SSI_2005/De signingaSENCERCourse.pdf
15. Bloom, B.S., 1956. Taxonomy of Educational Objectives, Handbook I: The Cognitive Domain. Addison Wesley Publishing Company, New York, ISBN: 10: 0582280109.

16. Student Assessment of Learning Gains, 2008. http://www.salgsite.org/

17. Bruntland, G.H., 1987. Our common future, chairman's foreword. http://www.undocuments.net/ocf-cf.htm

18. Eubanks, L.P., C.H. Middlecamp, C.E. Heltzel and S.W. Keller, 2009. Chemistry in Context. 6th Edn., McGraw-Hill, ISBN: 10: 0077221346, pp: 586. 